\title{
Cotidiano
}

\section{ORÁCULO, DESTINO E LIVRE ARBÍTRIO}

Claudia Maria Moura Pierre (1)

Compreendemos que há dois estados de consciência: o egóico e o divino, ou a consciência do Filho de Deus e a consciência do filho de Adão. A reflexão que ora tratamos transita entre estes dois estados de ser' - referimo-nos ao ego e apontamos para a verdade substancial.

Apressamo-nos em esclarecer que, em nível espiritual, não há necessidade de oráculo, posto que há um estado de comunhão perfeita entre Deus e Seu filho, o destino não é algo para onde ir, dada a unidade e a dimensão do eterno - em que o tempo não existe, e as ideias que permeiam o conceito de livre arbítrio perdem sentido considerando a liberdade como um dado absoluto, de maneira que somente há a realização da Vontade una.

O verbete oráculo vem do latim oraculum, que significa 'diminutivo de boca'. Podemos entender que, através da palavra, compreenderemos os desígnios de Deus, como que sua expressão falada. De acordo com o dicionário on line, "Na antiga Grécia e em Roma, [oráculo] era a resposta à pergunta feita a um deus. A palavra pode, também, significar o sacerdote ou outros recursos através dos quais a resposta era dada'(1). (www.dicio.com.br)

Por extensão, oráculo é a vontade e palavra de Deus anunciadas pelos profetas. Histórica e culturalmente, sempre houve a necessidade do ser humano em saber de seu destino - anunciado pelos oráculos - Talvez para encontrar um sentido em sua vida, talvez para suprir um sentimento de vulnerabilidade e, também, a fim de receber uma orientação divina para orientar a ação.

Um das principais premissas do oráculo é a consideração de que há um nível de realidade já 'escrito nas estrelas' e do qual não temos poder de intervenção. O oráculo, ao mesmo tempo que pode nos dar um sentimento de segurança, nos dá a sensação de sermos destituídos de todo poder por causa de nossa incompreensão do que seja o destino. O entendimento corriqueiro de destino é de algo sobre o qual não temos domínio. Achamos que nossa vida já está determinada por algo maior que nós, mas alheio a nós.

Outro fundamento do oráculo é noção de tempo, no qual nos movemos de um passado para um futuro. Nesta acepção, não temos condições de mudar o futuro e, também, o futuro não pode influenciar o passado, nem o presente. Não conseguimos superar esta noção de temporalidade linear. 
Assim, o oráculo fica circunscrito ao modo como sentimos o tempo, versando, geralmente, sobre um 'vir a ser' já determinado - o destino.

Em relação ao sentimento de vulnerabilidade, ele acontece porque não nos sentimos conectados com o divino. Mas, nosso lugar é em Deus, onde somos plenos e quando vivenciarmos esta plenitude, a comunhão com Deus, não haverá mais necessidade de recorrer a oráculos, pois em Deus nos sentimos seguros. Em Deus, já sabemos qual Sua vontade.

Sobre o determinismo dos acontecimentos, premissa dos oráculos - como revelação do destino,- vem-nos à tona o clássico dilema entre destino e livre arbítrio. Pois, neste estado de coisas, quem somos nós? Somos apenas marionetes dos eventos? Se assim for, onde está nosso livre arbítrio?

O livre arbítrio é o exercício da liberdade em relação à vontade - nossa vida depende das escolhas que fazemos livremente, por nossa própria vontade. No exercício do livre arbítrio, ás vezes escolhemos ser livres, às vezes, escolhemos ser escravos, no equívoco de fazermos escolhas que cremos serem boas, mas que não contribuem para nossa felicidade.

Quando se põe em questão estes dois conceitos, imediatamente vem a assunção de que existem duas vontades: a vontade de Deus e a vontade do homem. A vontade de Deus como algo alheio e em oposição à nossa vontade - como entidade independente e separada do divino.

Entretanto, uma sintonia maior com a espiritualidade vai nos revelar que a vontade de Deus é que sejamos felizes. $\mathrm{O}$ ego - a instancia da mente com a qual nos identificamos como entidades separadas - nos faz acreditar no mesmo. Não obstante, os mecanismos que o estado de consciência egóico usa para atingir este objetivo, nos levam à infelicidade, ao sofrimento.

A felicidade acontece justamente quando comungamos nossa vontade com a vontade divina, na medida em que perdoarmos, em que purificarmos nossas mentes e nossos corações de toda negatividade. Isto é o que vai nos salvar do mundo de tribulações. O ego, ao contrário, abriga pensamentos de ataque e condenação, não de perdão. Quando declara perdoar, é apenas para se afirmar como alguém melhor e superior ao outro, não é para desfazer-se da sentimentos negativos que nutre em relação ao mundo e às pessoas. Pelo contrário, todo tempo se afirma invalidando o outro. $\mathrm{O}$ ego declara constantemente o quanto é correto e bom, apontando para os erros e maldades dos outros. O ego se alimenta do julgamento, não do amor - que é o que nos leva à alegria. Efetivamente, desta maneira, a vontade de Deus e a vontade do ego é contraditória.

E o que vem a ser Destino? Retornar ao lugar de onde nunca saímos. Nosso destino é a restauração da mente a um estado de consciência perdido - o espiritual, o da consciência de Filho de Deus. Deus é o alfa e o ômega, o começo e o fim, o que não tem começo e não tem fim. O destino já somos, mas cremos que temos que ir.

A humanidade tem assumido 'destino' e 'livre arbítrio' como conceitos excludentes. De fato, nos moldes anteriormente descritos, quando utilizamos de livre vontade para contrapor à vontade divina, há uma oposição - podemos exercer o livre arbítrio para nos afastar de nosso destino, que é a 
felicidade. É interessante verificar que , em português usamos a expressão livre arbítrio, e em inglês utiliza-se freewill, para expressar o mesmo conceito. "Freewill", literalmente traduzido, significa vontade livre. Temos o poder de usar livremente nossa vontade para nos libertar do sofrimento, e podemos usar nossa vontade para nos acorrentar a ele.

No mais profundo de nosso ser, acredito que é de nosso livre arbítrio retornarmos para Deus e nosso destino é Deus. Lançamos mão do livre arbítrio para fazermos escolhas que aparentam adiar nossa liberdade, mas Somos em Deus. Ele é nossa origem e nosso fim. Sendo em Deus, somos plenos, portanto, nossa liberdade está em Deus - nossa liberdade está em nosso destino. Dito de outro modo: nossa liberdade é Deus, somos livres quando somos conscientes de nossa ligação com Deus. Se somos em Deus, Ele não é alheio a nós, mas 'um conosco'. Isto resolve a sensação angustiante de que estamos suscetíveis a algo alheio a nós. Se somos um com Deus, o poder não está alienado de nosso ser.

Não se pode negar que, muitas vezes, nossa experiência é de sermos completamente tragados pela ordem dos acontecimentos. Isto ocorre em função de nosso alheamento de nossa verdadeira natureza, que é divina. O domínio é próprio do Filho de Deus, não do filho de Adão.

Considerando que vivemos e nos movemos na crença de que somos separados de Deus, operamos a partir desta crença, que para nós é real. Toda nossa trajetória é a busca da consciência perdida, a superação deste sentimento de separação. Por causa deste senso de separação, há um caminho a ser percorrido por cada um de nós na procura do paraíso perdido. Este caminho compreende uma série de lições que temos que aprender, a fim de restaurar a consciência da unidade, a fim de retornar à condição de divindade. E, por isto há algumas situações pelas quais devemos passar, um percurso que devemos percorrer para voltar ao Reino, à condição antes da 'queda'. No 'final' da jornada, deixamos a condição humana e voltamos à condição de Filhos de Deus. Talvez esta trajetória venha a fundamentar os oráculos, tidos como revelações da vontade divina, ou simplesmente como comunicação do divino. O oráculo pode vir a ser um farol indicando caminhos a serem seguidos na trilha rumo à plenitude.

Acredito que existam lições que estão em nosso caminho, para que possamos aprendê-las, mas a cada escolha que fazemos, ou perpetuamos estas lições ou modificamos os caminhos, os acontecimentos. Estas escolhas são modos de responder aos eventos: como lidamos com eles? com raiva, inveja, ciúmes? trata-se das mínimas atitudes e respostas emocionais que damos aos eventos cotidianos. Cada vez que escolhemos julgar, retaliar, incitar discórdia, estamos optando pelo mundo adâmico. Cada vez que optamos por compreender, ser compassivos, perdoar, estamos unindo nossa vontade à do criador. No primeiro modo, adiamos nosso retorno ao Paraíso, no outro aceleramos a volta para casa, para a santidade; De uma forma, optamos pela a alegria, de outra, fazemos escolhas que nos levam ao sofrimento. Nossa vontade é sempre livre - usamos nossa liberdade de escolha para que propósito? - A resposta vai definir o curso dos acontecimentos, a cada momento. 
Os eventos, portanto, não são estáticos, nós o configuramos com nosso livre arbítrio - com nossa vontade -, nós o configuramos de acordo com a maneira com a qual lidamos com as situações, aprendendo as lições ou gerando situações que elas possam se repetir até que as tenhamos aprendido.

Nem sempre este caminho de volta para Deus é claro para nós, então confundimos o destino com uma ordem de realidade material, na qual procuramos emprego, companhia, negócios, situações e outros fatores ligados ao estado de consciência no qual nos encontramos. Não nos damos conta que nosso destino vai além do escopo desta existência material. Limitamos a interpretação de oráculo ao âmbito dos eventos terrenos. Num estado de consciência não esclarecido, cremos que a ponte é a terra firme, confundimos a plenitude com bens, condições e pessoas. Assim, quando recorremos a oráculos ficamos presos a acontecimentos mundanos, queremos saber sobre trabalho, relacionamentos, viagens, et. Neste estado de consciência perdemos a noção de destino como nosso encontro com o divino. Estamos apegados ao mundo material.

Mas somos seres empreendendo a volta para casa, somos nós que trilhamos a jornada do herói. O final desta jornada é determinada por nosso próprio ser superior, maior que nosso ego, mas não maior que nós, nem alheio a nós. E a trajetória desta jornada é determinada por nossas escolhas, por nossa vontade. E, não é alheio a nós porque é nossa própria vontade voltar para casa, nosso mais profundo anelo é encontrar nosso destino, que é Deus.

Até que tenhamos nos dado conta de que nossa vontade é a mesma vontade de Deus, viveremos em sofrimento. Faremos escolhas erradas, convencidos de que estas escolhas são de nosso real interesse. Repetindo: até que tenhamos unidade de vontade com o divino, escolheremos equivocadamente: o medo, ao invés do amor, as mágoas, ao invés do perdão, a condenação, ao invés da compaixão. Estas escolhas nos perpetuarão num estado de consciência adâmico, fora do Éden.

Toda nossa existência é um percurso rumo a si mesmo, à tomada de consciência de si. É a consciência tomando consciência da consciência. Esta é a jornada do herói - que somos nós. Daí a ideia de eventos já definidos - mas somos nós que definimos estes eventos, de acordo com nosso arbítrio. E, na medida em que somos um com Deus, somos co-criadores do universo. Vale lembrar que nosso destino é o retorno à origem, de onde nunca saímos. Como somos co-criadores da realidade, construímos a trajetória a partir de nossas escolhas. Vivemos o destino (já somos em Deus) e o livre arbítrio (fazemos escolhas) concomitantemente. Maravilhoso paradoxo.

Mesmo que façamos escolhas errôneas (por causa de nosso estado de consciência egóico), o retorno ao Éden é certo, sim, está escrito nas estrelas - mas como e quando retornaremos, será determinado pelas escolhas que fizermos a cada dia, em cada situação. Mesmo que façamos escolhas erradas, utilizando mal nosso livre arbítrio, não seremos impedidos de retornar ao Reino, apenas de atrasar este retorno. Nossa liberdade não nos impede nosso destino. E, o destino não consiste no final, nosso destino é nossa origem.

O divino já providenciou nossa salvação da condição humana. Esta é a única noção de determinismo que compreendemos neste caminho de volta. Nada do que fizermos ou deixarmos de 
fazer nos impedirá de retornar à glória, à unidade, à santidade. Entretanto, podemos, através de nossas escolhas, atrasar consideravelmente este retorno, através (da crença) de uma vontade dissonante da vontade divina. Mas o que é tempo, frente a eternidade?

Segundo Um Curso em Milagres, 'Livre Arbítrio não significa que podes estabelecer o currículo, significa apenas que podes escolher o que queres aprender em determinado momento' (Introdução). Não somos livres para continuarmos infinitamente na crença da separação.

Não há outro caminho que não seja para Deus (Para onde irei além de tua presença? Salmos 139:7). Entretanto, no mundo adâmico, sempre temos o poder de escolha: da luz para a escuridão, da escuridão para a luz, céu ou inferno, alegria ou dor, doença ou cura, acusar ou amar. A narração de Adão e Eva retrata bem isto, estando no estado paradisíaco de consciência, puderam escolher entre a árvore da Vida e a árvore do bem e do mal. Adão optou pelo bem e mal, e não pela unidade, escolheu o julgamento, e não o amor.

No Éden estava presente as duas opções possíveis. Entretanto, tendo o filho de Deus conhecido o conhecimento do bem e do mal - e sofrendo os efeitos deste conhecimento -, uma vez retornando ao Paraíso, não deixará de escolher corretamente,. A mesma situação é demonstrada na parábola do filho pródigo: tendo ele vivido segundo sua escolha de estar separado do pai, uma vez retornando para casa, não fará mais esta opção de viver separado, isolado. Mas a possibilidade de escolha estará presente.

Voltando ao ponto que nos deixa confusos, pela falta de compreensão: considerando que é impossível não sermos em Deus, a vontade dissonante não é uma escolha real, mas uma ilusão. Somente no estado ilusório - ou como afirma o livro do Gênesis, num sono profundo - é que podemos escolher estar fora do Paraíso. Cada vez que optamos pelo rancor, pela mágoa, é uma escolha errada que fazemos - pois não nos leva à alegria. E não é nossa verdadeira vontade.

Creio que, tendo o Filho de Deus retornado ao Éden, vai ter o poder de fazer escolhas (livre arbítrio) mas, neste novo estado de consciência, sempre escolherá corretamente, coerente com a vontade divina que é a Felicidade Perfeita; que é viver como Ele o criou - à imagem e semelhança de Deus.

Ao final, tendo se dado a unidade, a ilusão do mundo dual desaparece, e, na pura consciência crística, não há opções, não há escolhas - pois neste estado de ser, só existe a perfeição, só a verdade É. Há liberdade, mas não há escolhas. Porque só Deus É, só a vontade de Deus É. Em primeira e última instância, não pode existir a árvore da Vida e a árvore do conhecimento do bem e do mal. Algumas escrituras mencionam a Verdade e a ilusão, e a ilusão, sendo o que é, não existe. 'Somente a Verdade é verdadeira'.

* Importante afirmar que as considerações aqui feitas são frutos de um conhecimento intuitivo, livre reflexão e estudo de textos sagrados. De nenhum modo, existe a aspiração de se arvorar à expressão de verdades 
irrefutáveis. Mesmo para a autora, é possível que haja uma mudança de crença, em função de novas experiências e mudança de experiência em função de novas crenças.

\section{Sobre a Autora:}

(1) Cláudia Maria Moura Pierre é Socióloga, Professora da Universidade Regional do Cariri - URCA. Doutoranda em Educação pela Universidade Federal do Ceará e autora do livro Culpa, Cura e Relacionamento.

E-mail: claudiampierre@gmail.com

\section{Como citar este artigo (Formato ISO):}

PIERRE, C.M.M. Oráculo, destino e livre arbítrio. Id on Line Revista de Psicologia, Fevereiro de 2013, vol.1, n.19, p. 06-11. ISSN 1981-1189. 